JURNAL ANALIS KESEHATAN
KLINIKAL SAINS
UNIVERSITAS
ABDURRAB
http://jurnal.univrab.ac.id/index/php/klinikal

\title{
PEMANFAATAN SARI UBI JALAR UNGU(Ipomoea batatas poiret) SEBAGAI ZAT PEWARNA PADA PEWARNAAN GRAM TERHADAP BAKTERI Staphylococcus aureus DAN Escherichia coli
}

\author{
Rio Wahyu Septian Marbun, Febrizki Nabilah Mardanif, dan Uliya Fitri Aini \\ Sekolah Menengah Kejuruan Abdurrab \\ Jalan Delima No. 149, Panam, Pekanbaru \\ Telp. (0761)6705594 \\ e-mail :

\begin{tabular}{l} 
Info Artikel \\
\hline Sejarah Artikel \\
Diterima Juli 2020 \\
Disetujui November 2020 \\
Dipublikasikan Desember \\
2020
\end{tabular} \\ 2020 \\ Keywords: \\ Purple Sweet Potato \\ (Ipomoea batatas poiret), \\ Gram staining,

\section{Abstrak} \\ Ubi jalar ungu (Ipomoea batatas poiret) hampir terdapat di seluruh wilayah \\ Indonesia dan pada umbi ini menunjukkan adanya senyawa antosianin tinggi yang \\ bisa mewarnai bakteri. Selain itu,pada saat ini penggunaan zat warna pada bidang \\ laboratorium mikrobiologi cenderung harganya mahal dan sulit didapatkan. \\ Penelitian ini bertujuan untuk mengetahui apakah sari ubi jalar ungu bisa dijadikan \\ zat warna pada pewarnaan Gram terhadap bakteri Escherichia coli dan \\ Staphylococcus aureus. Penelitian ini dilaksanakan menggunakan metode \\ experimental laboratory secara in vitro. Hasil penelitian pada kelompok \\ eksperimen yang menggunakan sari ubi jalar ungu $\mathrm{pH}$ basa yang berperan sebagai \\ pengganti larutan gentian violet yaitu bakteri Staphylococcus aureus berbentuk \\ coccus dan berwarna violet sedikit kemerahan Dan pada kelompok eksperimen \\ yang menggunakan sari ubi jalar ungu $\mathrm{pH}$ asam yang berperan sebagai pengganti \\ carbol fuchsin, bakteri Escherichia coli berbentuk basil dengan warna merah. Ini \\ membuktikan bahwa sari ubi jalar ungu bisa dijadikan sebagai zat pewarna pada \\ pewarnaan Gram terhadap bakteri Staphylococcus aureus dan Escherichia coli.
} Staphylococcus aureus, Escherichia coli

Kata Kunci : Pewarnaan Gram, Ubi Jalar Ungu (Ipomoea batatas poiret), Staphylococcus aureus, Escherichia coli 
Keywords: Gram staining, Purple Sweet Potato (Ipomoea batatas poiret), Staphylococcus aureus, Escherichia coli

(C)2020 UniversitasAbdurrab

Alamat korespondensi:

ISSN 2338-4921

Jalan Delima No. 149

riowahyu0108@gmail.com

\section{PENDAHULUAN}

Indonesia adalah negara yang kaya akan hasil perkebunannya, salah satunya adalah ubi jalar ungu (Ipomoea batatas poiret) yang merupakan tanaman yang berasal dari daerah Amerika Tengah (Rukmana, 1997). Ipomoea batatas poiret) merupakan yang hidup disegala cuaca, di daerah pegunungan maupun pantai, mudah didapat, harganya relative murah, tidak memiliki efek samping bagi kesehatan, dan memiliki kulit dan daging yang berwarna ungu yang kaya akan pigmen antosianin yang lebih tinggi apabla dibandingkan dengan varietas lain sehingga daoat digunakan sebagai pewarna alami.(Winarti, 2008)Ubi jalar ungu memiliki kandungan antosianin yang paling tinggi dibandingkan dengan jenis ubi jalar lainnya, yaitu sebesar $282 \mathrm{mg} /$ $100 \mathrm{~g}$ bb (Ginting, Utomo and Yulifianti, 2015)

Adanya pigmen antosianin pada kulit hingga daging ubi jalar ungu, menyebabkan daging ubi jalar ungu mengandung zat warna ungu yang pekat (Sarwono, 2005). Musim dan lingkungan tumbuh tanaman menyebabkan perbedaan kadar antosianin (Damanhuri, 2005) Senyawa metabolit antosianin juga berkhasiat sebagai antioksidan, antihipertensi, dan mencegah gangguan hati (Apriyantono, 2002).

Antosianin termasuk dalam kelompok metabolit tumbuhan sekunder yang secara kolektif dikenal sebagai flavonoid, subkelas dari keluarga polifenol. Antosianin memiliki struktur yang terdiri dari dua cincin aromatik di kedua posisi. Kromofor dasar dari senyawa antosianin adalah ion 7-hydroxyflavilyum. Pigmen antosianin terdiri dari dua atau tiga unit kimia yaitu basa aglikon atau cincin flavylium (antosianidin), gula, dan kemungkinan kelompok asilasi (Bueno et al., 2012). Monoasil dari asam kafeat merupakan penyusun senyawa antosianin yang paling banyak terdapat pada ubi jalar ungu, sedangkan yang lainnya berupa diasil dari asam kafeat dan p- hidroksibenzoat atau asam kafeat dan asam ferulat. (Suda et al., 2003)

Pada $\mathrm{pH}$ asam pada ekstrak ubi jalar ungu lebih stabil dibandingkan pada $\mathrm{pH}$ basa, selain itu stabil pada kadar gula 50\%, stabil pada kadar garam 8\%, namun stabilitas akan terjadi 
Rio Wahyu Septian Marbun, Febrizki Nabilah Mardanif, dan Uliya Fitri Aini / Jurnal Analis Kesehatan Klinikalm Sains (2020)

menurun pada pemanasan sampai 60 menit. (Winarti, 2008). Pada pemanasan yang tinggi, kestabilan dan ketahanan zat warna antosianin akan berubah, selain pemanasan $\mathrm{pH}$ juga mempengaruhi stabilitasnya, dalam keadaan asam akan berwarna merah, dan keadaan basa akan berwarna biru. Senyawa antosianin juga tidak stabil dengan adanya oksihen dan asam askorbat. Hal ini menunjukkan bahwa zat warna antosianin memiliki kestabilan yang rendah (Winarno, 2004)

Pada sekarang ini, penggunaan zat warna sudah semakin luas terutama dalam makanan dan minuman, selain itu juga dilakukan pada bidang kesehatan khususnya di bidang laboratorium mikrobiologi, namun zat warna pada bidang mikrobiologi cenderung mahal dan sulit didapatkan. Pewarnaan Gram adalah salah satu cara untuk menggolongkan bakteri, yaitu bakteri Gram positif dan bakteri Gram negatif (Thomas Locke, Sally Keat, 2013). Salah satu bakteri yang termasuk Gram positif dan patogen yaitu Staphylococcus aureus dan bakteri yang termasuk Gram negatif yang patogen yaitu bakteri Escherichia coli

Bakteri Escherichia coli merupakan flora normal dalam saluran pencernaan manusia dan bakteri ini berbentuk batang, dan merupakan bakteri Gram negatif yang memiliki dinding sel yang tipis dan berlapis tiga, kandungan lipid pada dinding sel Gram negatif lebih tinggi (11-22\%) daripada pada dinding sel bakteri Gram positif dan peptidoglikan terdapat pada lapisan kaku (Pelczar, 1986). Bakteri Gram negatif mengandung lebih sedikit peptidoglikan (10-20\%), namun memiliki struktur membran yang terdiri dari protein, fosfolipida, dan lipopolisakarida (Volk, W.A. dan Wheeler, 1993)

Staphylococcus aureus merupakan bakteri Gram positif yang mempunyai struktur dinding sel yang tebal $(15-80 \mathrm{~nm})$ dan berlapis tunggal, namun memiliki kandungan lipid yang rendah (1-4\%), serta memiliki lapisan peptidoglikan dengan jumlah lebih dari 50\% selain itu Staphylococcus aureus bersifat tahan terhadap lisis yang disebabkan oleh enzim lysozim dan memproduksi enzim deoksiribonuklease dan fosfatase (Supardi, 1999)

Dalam pewarnaan Gram di laboratorium larutan gentian violet memiliki fungsi untuk mewarnai bakteri yang termasuk ke dalam Gram positif yang mana bakteri berwarn ungu dan larutan carbol fuchsin memiliki fungsi untuk mewarnai bakteri yang termasuk kedalam bakteri Gram negatif dengan hasil warna merah muda pada bakteri. Perkembangan perwarna alami pada pewarnaan bakteri pada saat ini masih sedikit. Berdasarkan hal tersebut maka diperlukannya suatu inovasi dalam pembuatan zat warna alami untuk pewarnaan bakteri.

Berdasarkan hasil penelitian sebelumnya yang dilakukan oleh Yuniarti dan Misbach tahun 2016, menunjukkan adanya kandungan senyawa antosianin yang dapat mewarnai bakteri Staphylococcus aureus Gram positif di Poltekkes Kemenkes Kendari (Misbach and Yuniarty, 2016). Berdasarkan latar belakang dia atas maka perlu dilakukan penelitian tentang 
Rio Wahyu Septian Marbun, Febrizki Nabilah Mardanif, dan Uliya Fitri Aini / Jurnal Analis Kesehatan Klinikalm Sains (2020)

Pemanfaatan Sari Ubi Jalar Ungu (Ipomoea batatas poiret) Sebagai Zat Pewarna pada Pewarnaan Gram terhadap bakteri Staphylococcus aureus dan Escherichia coli

\section{METODE}

Penelitian ini bersifat experiment laboratory secara in vitro yaitu melihat sari ubi jalar ungu dalam memberikan warna pada bakteri Staphylococcus aureus dan Escherichia coli. Penelitian ini telah dilakukan pada bulan November 2018 di Laboratorium Bakteriologi SMK Abdurrab Pekanbaru. Alat yang digunakan dalam penelitian ini diantaranya jembatan pewarnaan, pipet tetes, kain flannel, lampu spritus, objek glass, ose cincin, kertas saring, mikroskop, parutan, dancutter. Dan bahan yang digunakan, sari ubi jalar ungu, Gentien violet $10 \mathrm{ml}$, lugol, alkohol 95-96\% : $95 \mathrm{ml}$, danCarbol Fuchsin $10 \mathrm{ml}$.

\section{PROSEDUR KERJA}

\section{Pengambilan Sari Ubi Jalar Ungu (Ipomoea batatas poiret)}

Kupas kulit ubi jalar ungu kemudian cuci bersih ubi jalar ungu dan keringkan kemudian parut ubi jalar ungu kemudian timbang sebanyak 100 gr, lalu peras ubi jalar ungu yang telah diparut dengan menggunakan kain flannel, selanjutnya saring dengan menggunakan kertas saring

\section{Pembuatan Sari Ubi Jalar Ungu (Ipomoea batatas poiret) pH Asam dan pH Basa}

Untuk membuat sari ubi jalar ungu $\mathrm{pH}$ asam masukan sari ubi jalar ungu kedalam beaker glass kemudian teteskan larutan $\mathrm{HCl}$ tetes demi tetes sampai $\mathrm{pH}$ larutan menjadi asam dan untuk membuat sari ubijalar ungu $\mathrm{pH}$ basa masukan sari ubi jalar ungu kedalam beaker glass kemudian teteskan larutan $\mathrm{NaOH}$ tetes demi tetes sampai $\mathrm{pH}$ larutan menjadi basa

\section{Pewarnaan Gram Menggunakan Sari Ubi Jalar Ungu (Ipomoea batatas poiret) pH}

\section{Asam}

Membuat preparat menggunakan biakan murni Escherichia coli, kemudian preparat digenangi dengan Gentian violet selama 1 menit, setelah 1 menit bilas dengan air mengalir, selanjutnya genangi dengan larutan lugol selamal menit, setelah 1 menit bilas dengan air mengalir, kemudian genangi dengan alkohol selama 30 detik, selanjutnya genangi dengan larutan sari ubi jalar ungu $\mathrm{pH}$ asam selama 1 menit, hasil pengamatan dapat dilihat secara mikroskopis dengan perbesaran objektif 100x

\section{Pewarnaan Gram Menggunakan Sari Ubi Jalar Ungu (Ipomoea batatas poiret) pH} Basa

Membuat preparat menggunakan biakan murni Sthapylococcus aureus, kemudian preparat digenangi dengan sari ubi jalar ungu $\mathrm{pH}$ basa selama 1 menit. Setelah 1 menit bilas dengan 
Rio Wahyu Septian Marbun, Febrizki Nabilah Mardanif, dan Uliya Fitri Aini / Jurnal Analis Kesehatan Klinikalm Sains (2020)

air mengalir, selanjutnya genangi dengan larutan lugol selama1 menit, setelah 1 menit bilas dengan air mengalir. Kemudian genangi dengan alkohol selama 30 detik, selanjutnya genangi dengan larutan carbol fuchsin selama 1 menit. Hasil pengamatan dapat dilihat secara mikroskopis dengan perbesaran objektif 100x

\section{Pewarnaan Gram sebagai Kontrol}

Membuat preparat menggunakan biakan murni S. aureus dan E. Coli. Kemudian lakukan pewarnaan Gram, preparat control digenangi dengan larutan Gentian violet selama 1 menit. Setelah 1 menit bilas dengan air mengalir, selanjutnya digenangi dengan larutan lugol selama 1 menit, setelah 1 menit bilas dengan air mengalir. Kemudian genangi dengan larutan alkohol selama 30 detik, selanjutnya genangi dengan larutan carbol fuchsin 1 menit

\section{HASIL DAN PEMBAHASAN}

Hasil penelitian yang telah dilakukan dapat dilihat pada tabel dibawah ini

Tabel Hasil Pengamatan Mikroskopis Pewarnaan dengan Ubi Jalar Ungu Terhadap Bakteri Staphylococcus Aureus Dan Escherichia Coli

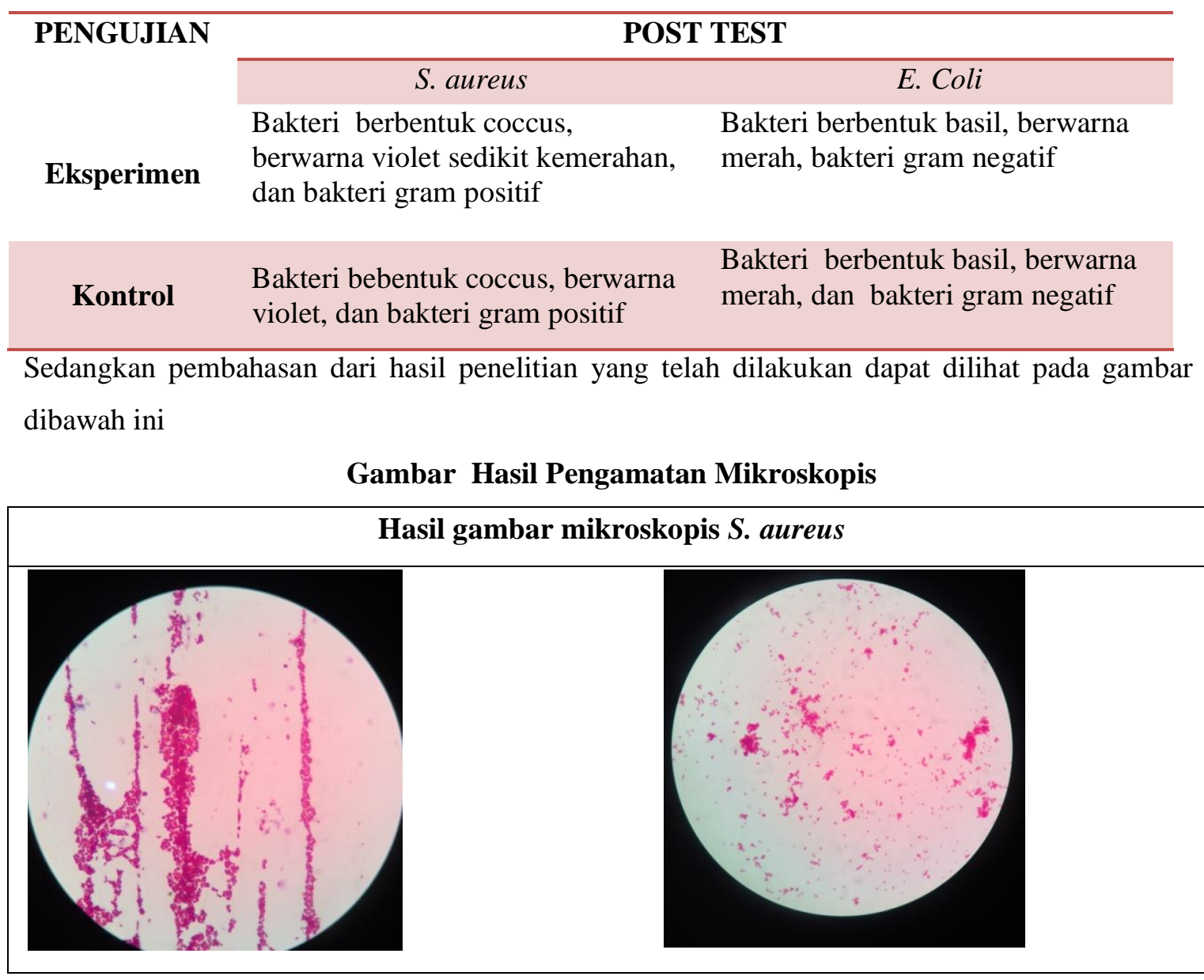

(a)

(b) 


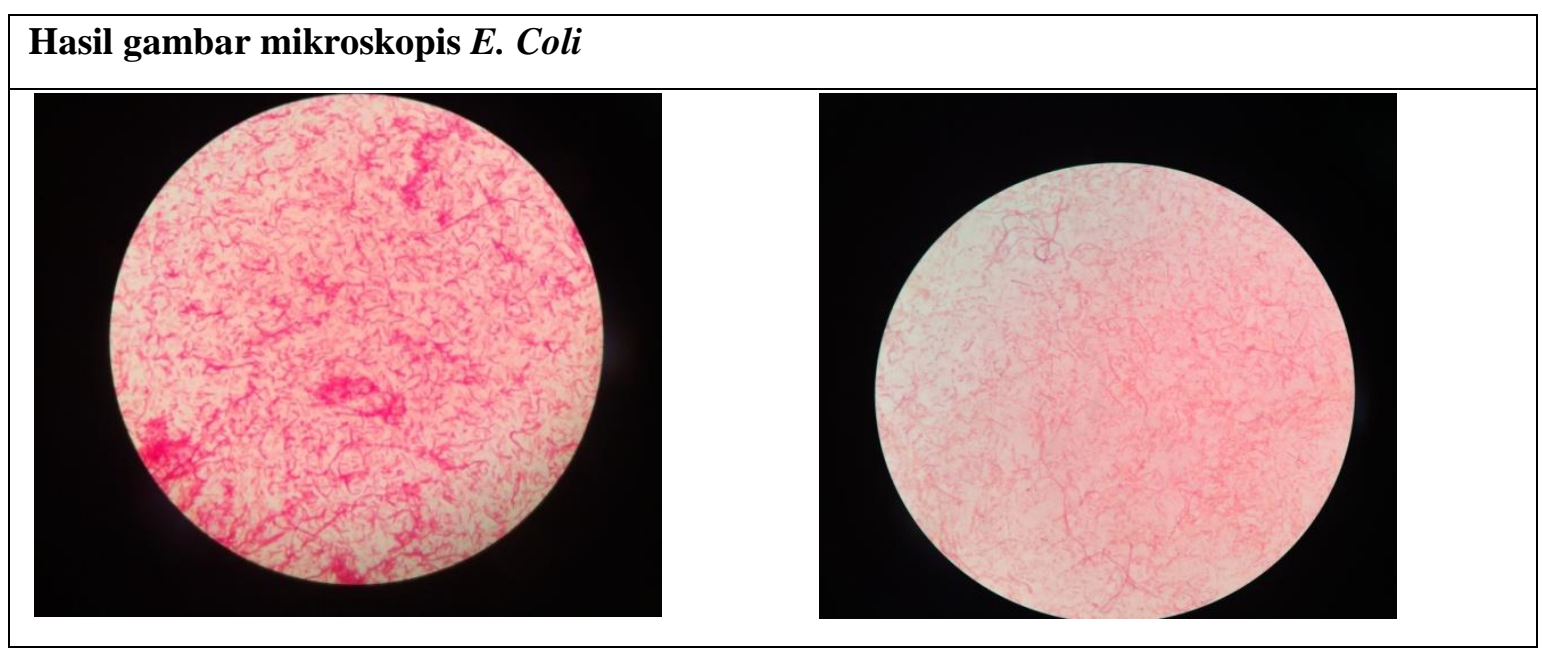

(b) (d)

Keterangan : (a) Gambar kontrol untuk S. aureus (b) Gambar hasil dengan pewarnaan ubi jalar ungu pada S. aureus (c) Gambar kontrol untuk E. Coli (d) Gambar hasil denagn pewarnaan ubi jalar ungu pada E.coli

Sari ubi jalar ungu dapat digunakan sebagai pewarna alami karena pada daging umbi ubi jalar memiliki pigmen alami yang disebut antosianin yaitu senyawa yang termasuk ke dalam golongan flavonoid. Senyawa fenol ini sama dengan kandungan yang terdapat dalam larutan carbol fuchsin dan gentian violet. Dalam eksperimen ini larutan sari ubi jalar ungu berfungsi sebagai zat pewarna pada pewarnaan bakteri Gram positif $S$. aureus dan Gram negatif E. coli

Pada penelitian ini terbagi atas dua kelompok yaitu percobaan pertama sari ubi jalar ungu $\mathrm{pH}$ basa sebagai zat warna terhadap bakteri S.aureus dan pada percobaan kedua yaitu sari ubi jalar ungu pH asam terhadap E.coli. Pada pewarnaan untuk kontrol, bakteri S.aureus akan mengikat zat warna pada larutan gentian violet dan bakteri E.coli akan mengikat zat warna pada larutan carbol fuchsin. Dan untuk sampel eksperimen, setelah diamati pada mikroskop lensa $100 x$, bakteri S. aureus yang telah diwarnai oleh larutan sari ubi jalar ungu bakteri berbentuk coccus dan berwarna ungu sedikit kemerahan, S.aureus berwarna ungu sedikit kemerahan karena bakteri akan mengikat zat warna pada antosianin yang terkandung dalam sari ubi jalar ungu pH basa. Sedangkan pada eksperimen kedua yaitu bakteri E.coli berbentuk basil atau batang dengan warna merahakan. Warna tersebut dikarekan bakteri E.coli mengikat zat antosianin yang terkandung dalam larutan sari ubi jalar ungu $\mathrm{pH}$ asam.

Mekanisme sari ubi jalar ungu $\mathrm{pH}$ basa dapat mewarnai bakteri Staphylococcus aureus menjadi berwarna ungu yaitu lapisan peptidoglikan pada dinding sel bakteri Gram positif yang 
Rio Wahyu Septian Marbun, Febrizki Nabilah Mardanif, dan Uliya Fitri Aini / Jurnal Analis Kesehatan Klinikalm Sains (2020)

bersifat asam hanya dapat mengikat larutan yang memiliki kadar $\mathrm{pH}$ yang basa dan hal ini sesuai dengan $\mathrm{pH}$ pada sari ubi jalar ungu (Misbach and Yuniarty, 2016). Pada saat pemberian larutan lugol maka zat warna yang telah diikat bakteri S.aureus akan semakin merekat, oleh karena itu warna bakteri tidak luntur pada saat proses dekolorisasi dengan alkohol. Serta tidak mengikat zat warna pada saat pemberian larutan carbol fuchsin (Winarti, 2008)

Pada bakteri Escherichia coli, mekanisme kerja pewarnaan sari ubi jalar ungu $\mathrm{pH}$ asam dapat mewarnai bakteri Escherichia coli yaitu lapisan peptidoglikan pada dinding sel bakteri Gram negatif yang memiliki lapisan lipid tidak dapat mengikat zat warna primer yaitu gentian violet, dan pada saat pemberian larutan lugol maka zat warna tidak merekat, oleh karena itu warna bakteri akan luntur pada saat proses dekolorisasi dengan alcohol karena lapisan lipid pada bakteri akan rusak sehingga pada saat pemberian zat warna sari ubi jalar ungu $\mathrm{pH}$ asam bakteri akan mengikat zat warna tersebut sehingga bakteri berwarna merah.

Zat warna antosianin merupakan pigmen alami yang dapat dimanfaatkan sebagai indikator $\mathrm{pH}$ alami yang pada media asam akan membentuk warna merah dan pada $\mathrm{pH}$ basa membentuk warna biru hingga kuning. Semakin rendah nilai $\mathrm{pH}$ maka warna akan semakin stabil. (Socaciu, 2007) Dalam pemanfaatan zat warna alami yaitu pigmen antosianin pada sari ubi jalar ungu dapat menjadi salah satu jawaban dari ketebatasan zat warna alami yang dapat digunakan pada media zat pewarnaan di bidang mikrobiologi yaitu pewarnaan Gram yang mana sari ubi jalar ungu memiliki fungsi yang sama dengan pewarna gentian violet dancarbol fuchsin.

\section{SIMPULAN}

Sari ubi jalar ungu ( Ipomoea batatas poiret) dapat dimanfaatkan sebagai zat warna alternatif pada pewarnaan Gram terhadap bakteri Staphylococcus aureus dan bakteri Escherichia coli

\section{UCAPAN TERIMA KASIH}

Peneliti mengucapkan terimakasih kepada kedua orang tua, guru pembimbing, dan teman-teman yang sudah memberikan dukungan dan bantuannya dalam menyelesaikan Karya Tulis Ilmiah (KTI) ini.

\section{DAFTAR PUSTAKA}

Apriyantono (2002) 'Pengaruh Pengolahan terhadap Nilai Gizi dan Keamanan Pangan'. Jakarta: Karumo Women dan Education.

Bueno, J. M. et al. (2012) 'Analysis and Antioxidant Capacity of Anthocyanin Pigments. Part II: Chemical Structure, Color, and Intake of Anthocyanins', Critical Reviews in Analytical 
Rio Wahyu Septian Marbun, Febrizki Nabilah Mardanif, dan Uliya Fitri Aini / Jurnal Analis Kesehatan Klinikalm Sains (2020)

Chemistry. Taylor \& Francis, 42(2), pp. 126-151. doi: 10.1080/10408347.2011.632314.

Damanhuri (2005) Pewarisan antosianin dan tanggap klon tanaman ubijalar terhadap lingkungan tumbuh. Disertasi. Malang: Fakultas Pasca Sarjana, Universitas Brawijaya.

Ginting, E., Utomo, J. S. and Yulifianti, R. (2015) 'Potensi Ubijalar Ungu sebagai Pangan Fungsional', Iptek Tanaman Pangan, 6(1).

Misbach, S. R. and Yuniarty, T. (2016) 'Pemanfaatan Sari Ubi Jalar Ungu ( Ipomoea Batatas Poiret ) Sebagai Zat Pewarna Pada Pewarnaan Staphylococcus Aureus’, Teknolab, 5(2), pp. 1-5.

Pelczar, M. J. dan E. S. . C. (1986) Dasar-Dasar Mikrobiologi I Terjemahan Ratna, S.H., Teja I, S. Sutarmi, dan Sri L.A. Jakarta: UI-Press.

Rukmana, R. H. (1997) Ubi Jalar : Budiaya dan Pasca Panen. Yogyakarta: Kanisius.

Sarwono, B. (2005) Ubi jalar: cara budidaya yang tepat, efisien dan ekonomis. Jakarta: Penebar Swadaya.

Socaciu, C. (2007) Food Colorants: Chemical and Functional Properties. London: CRC Press.

Suda, I. et al. (2003) 'Suda2003', 37(October 2002), pp. 167-173. doi: https://doi.org/10.6090/jarq.37.167.

Supardi, I. dan S. (1999) Mikrobiologi dalam Pengolahan dan Keamanan Pangan. Bandung: Alumni.

Thomas Locke, Sally Keat, A. W. dan R. M. (2013) Microbiology and Infectious Diseases on the move. Jakarta: PT Indeks.

Volk, W.A. dan Wheeler, M. . (1993) Volk Mikrobiologi Dasar 1 Terjemahan Soenarto A. Jakarta: Erlangga.

Winarno, F. . (2004) Kimia Pangan dan Gizi. Jakarta: Gramedia.

Winarti, U. S. dan D. A. (2008) 'EKSTRAKSI DAN STABILITAS WARNA UBI JALAR UNGU ( Ipomoea batatas L .,) SEBAGAI PEWARNA ALAMI', Jurnal Teknik Kimia, 3(1), pp. 207-214. 